\title{
Culture in Teaching English as a Foreign Language
}

\author{
Lidia Kostikova \\ Department of Foreign Languages \\ Ryazan State University named for S. Yesenin \\ Ryazan, Russia \\ E-mail: 1.p.kostikova@gmail.com
}

\author{
Varvara Prishvina \\ Department of Foreign Languages \\ Ryazan State Radio Engineering University \\ Ryazan, Russia \\ E-mail: varvarak1992@gmail.com
}

Oksana Fedotova

Department of Foreign Languages

Ryazan State University named for S. Yesenin

Ryazan, Russia

E-mail: ofedotova81@mail.ru

\author{
Anna Ilyushina \\ Department of Foreign Languages \\ I.P. Pavlov Ryazan State Medical University \\ Ryazan, Russia \\ E-mail: annailushina@mail.ru
}

\author{
Anatoliy Belogurov \\ Department of Pedagogy and Psychology \\ Moscow State Institute for International Relations \\ Moscow, Russia \\ E-mail: belogurov@mail.ru
}

\begin{abstract}
This paper examines the use of cultural approach to teaching English as a foreign language to university students who are actively involved in intercultural communication in their professional development. To improve the quality of English teaching, care should be taken in the fostering of multifaceted personal and the professional development in future specialists. Many modern researchers have explained the need and rationale for a wide range of cultural studies in combination with foreign language teaching. However, questions remain as to the content selection, forms of work and technologies that provide students with active interactions, and complete immersion. The paper focuses on the research questions: What professional training can English teachers have in the context of global culture? How can cultural knowledge and understanding be incorporated into the context of English language classes? What specific strategies can make students more culturally competent? Findings show that future English teachers have a better awareness of art and culture if the culturally sensitive approach to foreign language teaching is used in their professional training as it enables them to use their new knowledge of a culture in situations of intercultural communication. It supports them in becoming more joboriented. Cultural studies boost their motivation and create an atmosphere of curiosity and openness. Thirty four respondents took part in the questionnaire.
\end{abstract}

Keywords-culturally sensitive approach; foreign language teaching; English language; English teachers

\section{INTRODUCTION}

Modern culture is quite international. People of art musicians, singers, painters, actors, sculptors, and others - have numerous world events where they demonstrate their achievements, their talent, and their inspiration. They are participants of intercultural communication and use English as a lingua franca. There is no doubt that English has become the global language of culture and art. There is a behind-thescenes name for it - International Art English (IAE) - which is used in such media as gallery press releases or exhibition announcements meant for a wide audience.

The curricula of universities usually include a compulsory course in foreign languages. Teachers-intraining at these universities are expected to shape humanist values in the youth of today, to keep and spread their national cultures, and to develop respect for the diversity of world cultures. However, it is necessary to develop their cultural awareness, and to give them tools and understanding to discuss problems of art and culture in the language classroom so that IAE will not diminish as an exclusive private language.

Though the problem is of great importance now, not many works are devoted to the cultural content of professional training of future English teachers. In the meantime, learners' receptive and productive skills can be developed by engaging with pieces of art from the classical era to the modern period.

\section{METHODS AND MATERIALS}

The objective of this research is to assess future English teachers' attitudes and views on the job-oriented training. It is also vital to learn if students can see the importance of culture in education. 
The methods used in the research are both theoretical and empirical. The theoretical methods are represented by: analysis, description, and comparison and systematization of publications by Russian and foreign researchers. First, works on culture were studied (S. G. Ter-Minasova, C. Kramsch, et al.). Second, articles on teachers' education were analyzed (A. Yu. Belogurov, et al.). Third, the principles of teaching foreign languages in higher education were investigated (E. V. Voevoda, L. P. Kostikova et al.). It was decided that job-oriented training is necessary for future English teachers in their pre-service education. It will greatly add to the quality of language teaching. Finally, the legacy of Ancient Greece was studied. In the context of teaching culture, the art of Ancient Greece is seen as a never-fading source of knowledge of civilizations and cultural systems.

It is clear that the job-oriented training of future English teachers is of crucial importance for their future employment. Obviously, the concept of culture seems very complex and quite overwhelming for students as a subject to be discussed in the English language classroom. That is why it has been chosen as a basis for investigating the process of future English teachers' job-oriented training in the context of global culture.
The empirical methods include: observations of students studying the issues of ancient cultures, such as the culture of Ancient Greece; analysis of their work in a distance learning course at LMS Moodle; systematization of the authors' personal practical experience of discussing cultural issues with future teachers; a questionnaire; and comparative data analysis [1].

The study was conducted at Ryazan State University named for S. Yesenin in the Department of History and International Relations with Fourth-Year students. These are future English teachers whose job-oriented language training is based on the principles of integration of professional interests with an emphasis on the development of students' linguo-sociocultural competence when integrated into their professional competence [2].

A special questionnaire taking into consideration the concepts of culture and job-oriented training was developed to interview the students. The survey was completed by 34 respondents.

Four components and corresponding statements were offered in "Table 1". The respondents had to express their agreement or disagreement and put a tick in the appropriate column, allowing the grading of their answers.

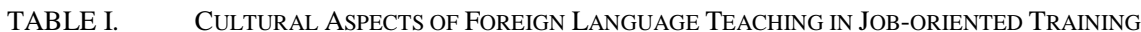

(Express your agreement or disagreement: put a tick in the necessary column, grading your answer).

\begin{tabular}{|c|c|c|c|c|c|}
\hline The Criteria & The statements & Yes & I partially agree & No & I cannot answer \\
\hline $\begin{array}{l}\text { Cultural } \\
\text { awareness training }\end{array}$ & $\begin{array}{l}\text { It is important to discuss different aspects of cultures with } \\
\text { teachers-to-be. }\end{array}$ & & & & \\
\hline $\begin{array}{l}\text { Job-oriented } \\
\text { training } \\
\text { perspectives }\end{array}$ & $\begin{array}{l}\text { I believe that cultural awareness training will help me } \\
\text { succeed in working internationally. }\end{array}$ & & & & \\
\hline \multirow{2}{*}{$\begin{array}{l}\text { The use of art in } \\
\text { the English } \\
\text { language } \\
\text { classroom }\end{array}$} & $\begin{array}{l}\text { Viewing visual arts in class helps me understand their } \\
\text { purposes, interpretations and relationships. }\end{array}$ & & & & \\
\hline & $\begin{array}{l}\text { Resort to art makes learning more varied and broadens the } \\
\text { range of classroom topics. }\end{array}$ & & & & \\
\hline \multirow[t]{2}{*}{$\begin{array}{l}\text { Ways of } \\
\text { presenting art }\end{array}$} & $\begin{array}{l}\text { Doing art tasks in the distance learning course gives me } \\
\text { more autonomy and develops creative mindset. }\end{array}$ & & & & \\
\hline & $\begin{array}{l}\text { Collaborative learning by making leaflets, preparing guided } \\
\text { tours or audio guides makes learning environment creative. }\end{array}$ & & & & \\
\hline
\end{tabular}

\section{DEFINITION OF CULTURE}

Culture is undoubtedly an integral part of foreign language teaching and a wide range of cultural topics are covered in a modern language classroom. The world community considers language fluency as one of the greatest values of education because linguistic diversity is definitely an essential element of cultural diversity [3]. Language skills serve as a litmus test for reflecting current problems of society, and communication challenges in particular [4]. Still, there is debate on the approaches and perspectives caused by different understanding of culture and its continued impact on education. "Culture itself is a notoriously difficult term to define. This is because cultural groups are always internally heterogeneous groups that embrace a range of diverse practices and norms that are often contested, change over time, and are enacted by individuals in personalized ways" [5]. A modern definition of culture must account for the new realities: "If culture is no longer bound to the territory of a nation-state and its history, then we have to see it as a dynamic discursive process, constructed and reconstructed in various ways by individuals engaged in struggles for symbolic meaning and for the control of subjectivities and interpretations of history" [6].

There is a rough distinction between the material, social, and subjective aspects of culture. This study is particularly interested in social culture which is represented by social institutions and subjective culture expressed in beliefs, values, norms, and discourses. Groups may form distinctive subcultures as the set of cultural resources is distributed across them and the members use only the subset appropriate and available for them. Consequently, "all people belong simultaneously to and identify with many different cultures" [7]. Understanding between these cultures and their interaction is possible through the dialogue of cultures which is carried out by means of language. "The dialogue of 
cultures is equitable cooperation of cultures based on the mutual understanding of their representatives. Understanding in all its forms - linguistic, socio-cultural and axiological (awareness and understanding of the values of another culture, a dialogue partner) and many others - is the foundation and goal of the dialogue among cultures" [8].

\section{The Way We Teach CUlture IN THE Foreign LANGUAGE CLASSROOM}

There are two broad approaches to teaching culture to be examined: the intercultural approach and the traditional approach. In both cases, the primary objective is propagation of intercultural action skills: Students must be able to identify differences between foreign and familiar cultures and develop strategies to understand the particularities of another culture with the objective of preventing any intercultural misunderstandings [9]. To achieve these goals, the teacher has to act as a mediator between the native language and the target language cultures. D. Atay highlights the changing role of the teacher: "Teachers are expected not only to teach the foreign linguistic code but also to contextualize that code against the socio-cultural background" [10]. With the intercultural approach, the primary focus of teaching is "on the target cultures, yet, it also includes comparisons between the learner's own country and target country, thereby helping learners to develop a reflective attitude to the culture and civilization of their own countries" [10]. In other words, adherents of this approach acknowledge that foreign language teaching helps transmit cultural property.

However, the traditional approach also has its advocates. Among them is L. Volkmann who refers to the concept of Landeskunde which is most commonly understood as the traditional way of teaching a culture by means of learning a foreign language. The Landeskunde concept is aimed at familiarizing students with cultural products of the target language country and developing their communicative competence but it does not place successful intercultural communication at the forefront [11]. The distinctive features of the two approaches lead to the conclusion that both communicative and intercultural competences are the foundation of effective communication and, most importantly, it is what the labor market seeks. As stated by A. P. Liferov and L. P. Kostikova, "The gap between the quality of graduate education and the demands of a modernizing society is one of the causes of an educational crisis both in Russia and in the world" [12].

The question now becomes how to teach culture in the language classroom and what risks and pitfalls are likely to appear. C. Kramsch illuminates the students' attitude towards the cultural component of foreign language study. It should be kept in mind that "some learners feel threatened in their L1 identity by too much emphasis on culture" [13]. Yet, others eagerly grasp the opportunity of getting access to another culture while, at the same time, learning to appreciate their own [13]. Another concern is the relationship between the European standards of language skills and the actual language proficiency developed in response to communication needs. Consequently, there is a need for raising the existing standards and, more importantly, of promoting cooperation in the European educational space [14]. As for the approaches to teaching culture, the key is undoubtedly experiential learning or learning by doing. It involves "experience, comparison, analysis, reflection and co-operative action" [15]. Teachers are equipped with a wide range of innovative techniques and work forms facilitating the learning process: project work, storytelling, role play, simulations, theatre, poetry, creative writing, ethnographic tasks, use of films, image-making/still images in class, and social media and other online tools [15]. All the approaches, methods, and techniques have to address the students' potential and comply with their level of knowledge, professional and personal interests, and motives. "The challenges faced by teachers got more complicated and require the capacity for providing dialogue with students and readiness for professional creativity" [16].

\section{DATA ANALYSIS AND RESULTS}

Qualitative data collection was conducted through a special questionnaire that allowed students to express their attitude about studying cultural aspects during the process of foreign language teaching in job-oriented training. To determine self-identified cultural orientation, students were asked to express their opinions about four components of culture-oriented language learning in "Table I".

The analysis of the students' answers is provided below:

\section{- Cultural awareness training}

The students demonstrated their willingness to participate in the culture-oriented discussion. Half of the students (17 participants) agreed with the statement and 15 students chose the "partially agree" variant. No one disagreed. Two participants did not answer.

\section{- Job-oriented training}

The connection between cultural awareness and professional international perspectives is not so clear to students. 10 participants agreed completely, 12 agreed partially, 10 disagreed, and 2 failed to answer.

\section{- The use of art in the English language classroom}

The respondents believe that viewing visual arts in class helps them better understand their purposes, interpretations, and relationships. They also support the statement that the use of art makes learning more varied and broadens the range of classroom topics. The answers were distributed in the following proportion: 20 participants agreed, and 14 agreed partially.

\section{- Ways of presenting art}

Surprisingly, students supported different ways of presenting cultural aspects in the process of language learning and teaching. 20 participants agreed or partially agreed with the effectiveness of distance learning technologies. 14 saw more benefit in collaborative classroom training. Among them 10 students supported both ways of studying art. 
Generally, the respondents show their agreement to all the components of the questionnaire but there is a certain correlation between those to which students give precedence in "Fig. 1".

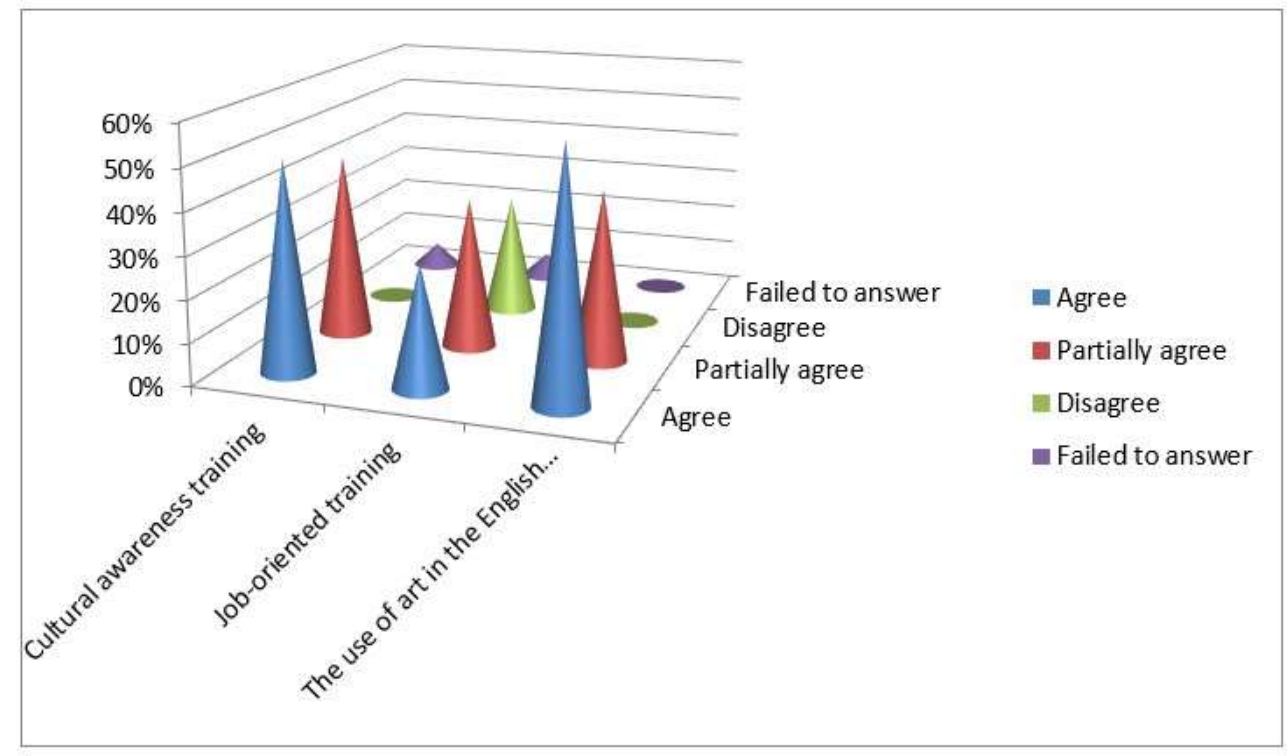

Fig. 1. Comparative analysis of the university students' assessment of three components of foreign language teaching in job-oriented training.

The results show that future English teachers strive to study culture as a source of new knowledge. They consider discussions of art a beneficial component of foreign language learning, which develops creativity and makes classroom and distance learning more varied and richer in topics. Nevertheless, the participants of the questionnaire are not convinced that socio-cultural knowledge will contribute to their professional work and that belief, subsequently, draws attention to the problem of cultivating cultural awareness as an integral part of foreign language teaching and the related technologies to focus upon. By analyzing the students' answers, it is possible to see their preferences in using distance learning technologies as they are given more autonomy and develop creative mindsets in "Fig. 2".

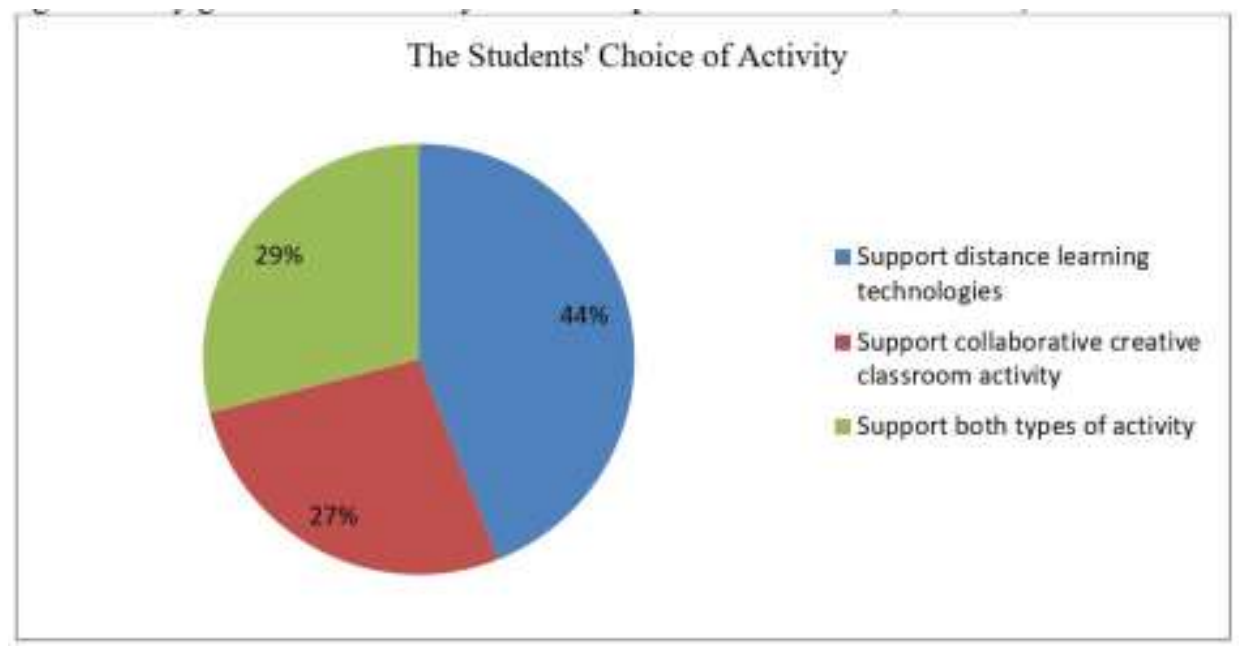

Fig. 2. Comparative analysis of the students' choice of activity in the way of presenting art in the English classroom.

In this endeavor, the teacher takes the role of a companion and a constructive force for change in the students' perception of their place as professionals in the modern world. The interests and opinions of students should be given priority in choosing the most suitable and flexible class formats.

\section{CONCLUSION}

The foreign language teaching in job-oriented training uses varied content which is mainly focused on developing communication skills in certain professional and scientific areas. Job-oriented training involves a combination of mastering the language, developing students' personality and attitude, and cultural awareness. Special attention should be given to teaching cultural aspects of the target language so as to make the students more sophisticated and socially skilled 
in the diverse world. Due to the internationalized character of the art world, its language is unique, and it cultivates both universally shared and local values and beliefs. In foreign language classes, students can consider the origin of modern cultures and speculate about their meaning while analyzing the most significant pieces of art. Following this path, future teachers can make their cultural education a lifelong process.

\section{REFERENCES}

[1] L. P. Kostikova, Multi-media e-module "Developing Intercultural Competence of University Students while Studying the Course "History through Art. Ancient Greece" // The Chronicles of the consolidated fund of electronic resources "Science and Education", 2014, No. 10 (65), p. 38.

[2] L. P. Kostikova, Teaching English for Specific Purposes to Students of History // The Psychological and Pedagogical Search, 2012, no.4 (24), pp.106-111.

[3] E. V. Voevoda, A. Yu. Belogurov, L. P. Kostikova, N. M. Romanenko, M. V. Silantyeva, Language Policy in the Russian Empire: Legal and Constitutional Aspect / Politica della lingua nell'Impero russo: aspetti legali e constituzionali / // Giornale di Storia constituzionale / Journal of Constitutional History, 2017, vol.33, no.1, pp. 121-130.

[4] E. V. Voevoda, Foreign Language Mediation Activities in the Dialogue of Cultures // Journal of Moscow State Institute of International Relations (University), 2015, no. 3 (42), pp. 239-243, p. 240.

[5] Developing intercultural competence through education, series editor Josef Huber, edited by Josef Huber and Christopher Reynolds. Council of Europe Pestalozzi Series No.3, Council of Europe publishing, January 2014, printed at the Council of Europe. pp. 13-14.

[6] C. Kramsch. Culture in Foreign Language Teaching. Iranian Journal of Language Teaching Research, 2013, no. 1(1), pp. 57-78.

[7] Developing intercultural competence through education. p. 14.

[8] S. G. Ter-Minasova, War and peace of languages and cultures: theory and practice of inter-lingual and intercultural communication. M.: Slovo, 2008. 334 p. p. 18.

[9] Blioumi, Intercultural skills, culture and literature at the university. International Journal of Language, Translation and Intercultural Communication, 2015, vol. 2, pp. 4-13.

[10] D. Atay, G Kurt, Z Çamlıbel, P Ersin, Ö Kaslığlu, The role of intercultural competence in foreign language teaching // Inonu University Journal of the Faculty of Education, 2009, vol. 10, No. 3, pp. 123-135.

[11] L. Volkmann, Aspekte und Dimensionen interkultureller Kompetenz. In L. Volkmann, L, Stierstofer und W. Gehring: Interkulturelle Kompetenz. Konzepte und Praxis des Unterrichts. Tübingen: Gunter Narr Verlag, 2002, pp. 11-47.

[12] A.P. Liferov, L. P. Kostikova, Russian Higher Education Meeting Challenges of 21st Century Labour Market // International Journal for 21st Century Education. Special Issue: Challenges of 21st Century Education in Europe, December 2017, pp. 51-58.

[13] A. Kramsch, Culture in Foreign Language Teaching, p. 59.

[14] E. V. Voevoda, Foreign Language Mediation Activities in the Dialogue of Cultures.

[15] Developing intercultural competence through education, p. 37.

[16] A.Yu. Belogurov, Strategy and methodology of teachers' professional development during all life // Pedagogy, 2016, No. 7, p. 58-63. 